\title{
KOMPETENSI KARYAWAN DAMPAKNYATERHADAP KEUNGGULAN BERSAING ORGANISASI BISNIS UMKM
}

\author{
Muhamad Rifa'i \\ Fakultas Ekonomi Universitas Tribhuwana Tunggadewi Malang \\ rifaiunitri@gmail.com; \\ As'ari \\ Fakultas Ekonomi Universitas Tribhuwana Tunggadewi Malang \\ asari_maduranis@ymail.com \\ Poppy Indrihastuti \\ Fakultas Ekonomi Universitas Tribhuwana Tunggadewi Malang \\ indrihastuti.poppy@gmail.com
}

\begin{abstract}
Abstrak
Organisasi bisnis hidup di dalam lingkungan yang kompetitif, untuk itu organisasi bisnis senantiasa melakukan upaya-upaya yang dapat memperkokoh keberadaannya dengan menciptakan keunggulan bersaing didalam lingkungannya. Upaya ini bisa dilakukan jika organisasi bisnis memiliki karyawan yang kompeten. Namun, permasalahan yang seringkali dihadapi organisasi bisnis ialah kurang tersedianya karyawan yang memiliki kompetensi yang cukup untuk menjalankan strategi bisnis hingga mampu menciptakan keunggulan bersaing. Disinilah peran dan tanggungjawab manajemen karyawan untuk mampu mengatasi permasalahan tersebut.Tujuan penelitian ini adalah untuk mengetahui dan menganalisis bagaimana pengaruh variabel kompetensi karyawan (organized, rareness, valuable, dan inimitable) terhadap pencapaian keunggulan kompetitif, baik itu secara simultan dan parsial, serta mengetahui dan menganalisis variabel manakah yang berpengaruh dominan terhadap keunggulan kompetitif perusahaan. Dari hasil penelitian analisis regresi ganda antara variabel bebas kompetensi karyawan memberikan pengaruh yang signifikan terhadap variabel terikat yaitu pencapaian keunggulan kompetitif organisasi pada perusahaan.
\end{abstract}

Kata Kunci: kompetensi, keunggulan bersaing, organisasi bisnis.

\section{PENDAHULUAN}

Saat ini pengelolaan terhadap organisai bisnis termasuk usaha kecil dan menengah (UMKM)perlu semakin ditingkatkan. Hal ini disebabkan adanya peningkatan persaingan di lingkungan bisnis. Organisasi bisnis termasuk UMKM perlu melihat bahwa fungsi pegawai merupakan kontributor utama terhadap pencapaian visi dan misi suatu organisasi, serta sebagai sumber keunggulan bersaing. Keunggulan bersaing saat ini menjadi suatu persoalan dalam sebuah perusahaan untuk mengahadapi dunia globalisasi yang modern, dikarenakan semakin banyak industri-industri yang menerobos jenjang kualitas produk yang diproduksinya, baik itu melalui kompetensi karyawan dan teknologi modern.Perusahaan akan terus mengembangkan potensi karyawan yang memiliki kompetensi atau standar sektor ekonomi nasional dan global. 
Kompetensi karyawan yang dimaksud disini adalah terorganisasi yang sesuai dengan visi dan misi perusahaan (organized), mempunyai nilai (valuable), kemampuan yang tidak mudah ditiru oleh orang atau organisasi lain (inimitable), dan keterampilan yang langka (rareness). Dari empat kompetensi inti tersebut mempunyai hubungan antara satu dengan yang lainnya, sehingga core competencies ini mampu mengembangkan organisasi atau industri, baik industri lokal maupun non-lokal.

Salah satu faktor yang paling penting dan mampu menentukan keberhasilan atau kegagalan suatu organisasi bisnis UMKM adalah faktor sumber daya manusia. Keunggulan bersaing (competitive advantage) suatu organisasi sangat ditentukan oleh kualitas sumber daya manusianya. Oleh karena itu, penanganan sumber daya manusia harus dilakukan secara menyeluruh dan seksama dalam kerangka sistem pengelolaan sumber daya manusia yang bersifat strategis, menyatu dan selalu terhubung, sesuai tujuan dan visi misi organisasi.Untuk memiliki kompetensi yang mendalam dan menyeluruh, sebaiknya organisasi bergantung pada kerangka visi organisasi itu sendiri (organization vision framework), karena hal ini merupakan sebuah core ideologi yang terdiri atas core value dan purposes dimasa depan, yang selalu diimpikan oleh setiap organisasi. Jadi, tanpa adanya organized, valuable, rareness dan inimitable, maka core competences tidak akan tumbuh berkembang dengan subur pada tujuan organisasi tersebut.

Keunggulan bersaing adalah jantung dari kinerja usaha UMKM untuk bersaing dilingkungan pasar kompetitif. Namun, sesudah beberapa dasawarsa perluasan dan kemakmuran yang hebat, banyak perusahaan kehilangan pandangan terhadap keunggulan bersaing sehingga bisa berkembang dan mengejar diversifikasi. Pentingnya keunggulan bersaing saat ini pastilah lebih besar. Pada dasarnya, keunggulan bersaing berkembang dari nilai yang mampu diciptakan oleh perusahaan terhadap konsumennya. Keunggulan bersaing mungkin mengambil bentuk harga yang lebih rendah dibandingkan harga pesaing untuk manfaat yang sepadan atau menyediakan manfaat unik yang lebih dari sekedar mengimbangi harga premi (Poter: 1985).

Oleh karena itu, core competencies yang ada pada setiap organisasi seharusnya mempunyai sifat khas bagi organisasi itu sendiri. untuk dapat menggunakan Core competences secara efektif, maka dipastikan harus mampu menjawab tantangan dari para pesaingnya, yang disebut keunggulan bersaing atau competitive advantage. Dengan demikian, apabila organisasi mulai mengkonsentrasikan diri pada core competencenya, maka organisasi tersebut harus cepat memberikan perhatian yang lebih banyak dan berfokus pada kompetensi dari anggota atau karyawannya.Sebab, salah satu variable pembentuk core competence organisasi yang baik adalah dari kompetensi individu karyawannya itu sendiri. Apabila kompetensi individu sudah sesuai dan selaras dengan core competence organisasi, maka akan tercipta competence based organization atau organisasi yang berbasis kompetensi.

Mendefinisikan kompetensi tenaga kerja bukanlah hal yang mudah, oleh karena itu diperlukan komunikasi antar karyawan dengan pihak perusahaan agar kompetensi yang diinginkan atau dibutuhkan oleh perusahaan dapat dikenali dan dinilai dalam berbagai situasi organisasi yang 
berbeda, sebab ada perbedaan antara kompetensi individu dengan core competence organisasi. Pimpinan perusahaan harus terlibat langsung dalam proses transformasi kompetensi individu menjadi core competence organisasi. Transformasi tersebut bukan hanya sekedar masalah pelatihan, tetapi harus melibatkan seluruh karyawan dalam organisasi agar dapat bekerja sama dalam sebuah jejaring kerja dan menciptakan visi dan misi yang baik (Moeheriono, 2010). Perusahaan akan selalu memikat, mengembangkan dan mempertahankan karyawan yang mempunyai keterampilan inovatif, dan agar karyawan tetap bertahan bekerja di perusahaannya, maka diperlukan lingkungan pembelajaran yang berkelanjutan. Bagaimana misalnya para karyawan secara bertahap dikembanagkan potensi dirinya untuk memiliki pemikiran kompetitif, sinergis dan pemikiran global. Dengan demikian, perusahaan akan semakin siap dalam menghadapi setiap proses perubahan lokal dan global. Hal demikian tampak jelas di suatu organisasi pembelajaran (Mangkuprawira, 2002).

\section{KAJIAN PUSTAKA \\ Pengertian Kompetensi}

Menurut Wibowo (2007:86)
yaitu: "suatu kemampuan untuk melaksanakan atau melakukan suatu pekerjaan atau tugas yang dilandasi atas keterampilan dan pengetahuan serta didukung oleh sikap kerja yang dituntut oleh pekerjaan tersebut". Menurut Spencer \& Spencer (1993:9) kompetensi adalah sebagai karakteristik yang mendasari seseorang dan berkaitan dengan efektifitas kinerja individu dalam pekerjaannya (an underlying characteristic's of individual which is causally related to criterion referenced effective and or superior performance in a job or situation).

\section{Menentukan Kompetensi}

Menurut Veithzal dan Ella (2009:304) ada tiga cara untuk menentukan kompetensi, diantaranya adalah: (1) Melakukan studi kalasik kompetensi. Mengawali dengan mendefinisikan kreteria kinerja yang efektif pada masing-masing pekerjaan, dan memilih sampel dari dua kelompok pekerja, yaitu mereka yang sangat baik prestasinya dan mereka yang berprestasi rata-rata; (2) Melakukan perbandingan dan analisis mengenai kompetensi apa saja yang dimiliki para top performers yang tidak dimiliki para average performers. Maka dengan demikian, deskripsikan tingkat masing-masing kompetensi tersebut; dan (3) Melakukan validasi atas kompetensi-kompetensi yang berhasil diidentifikasi, lalu menerapkan aplikasi model kompetensi tersebut. Dengan langkah-langkah itulah yang perlu dilakukan untuk mendapatkan kompetensi yang akurat, sesuai dengan kebutuhan dan kondisi organisasi.

\section{Keunggulaan Berbasis Kompetensi}

Suatu kompetensi dapat dikatakan apabila memenuhi syarat syarat tertentu. Yang utama, syarat untuk kompetensi adalah keterbukaan terhadap pasar baru, kemungkinankemungkinan baru, sifat yang adaptif. Manager suatu perusahaan yang memiliki suatu kompetensi harus berpikir tentang bagaimana seperangkat keterampilan yang terintegrasi diterapkan pada domain-domain produk baru. Oleh karena itu pandangan yang berbasis kompetensi berangkat dari fokus pada strategi level bisnis dan mulai menghadapi strategi level korporasi, dan menentukan jenis usaha (bisnis) yang tepat. (dalam soebagio dan wahyudi, 2008, hal,188-189). 
Pengertian Kompetensi Inti (core competencies)

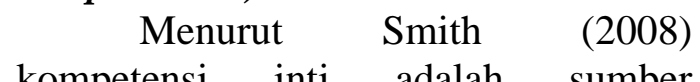
diferensiasi bagi perusahaan yang memampukan mereka untuk membuat dan menawarkan produk, layanan, dan solusi yang unik bagi pelanggan (dalam Devina dan Devie 2013).Kemampuan yang dimiliki sebuah perusahaan dapat dikategorikan sebagai kemampuan yang core (inti), hanya jika kemampuan tersebut dapat membedakan suatu perusahaan dari pesaingnya secara strategis (Leonard dalam Devina dan Devie 2013).Prahalad and Hamel (1990) mendefinikan kompetensi inti (core competencies) adalah pengetahuan perusahaan yang kolektif tentang bagaimana mengkoordinasi keterampilan produksi dan teknologi yang beragam.Sejalan dengan definesi tersebut, Fiol berpendapat bahwa core competencies merupakan gabungan tertentu dari keterampilan dan sumber daya yang dimiliki perusahaan, serta sumber daya tersebut digunakan untuk memproduk hasil (dalam dalam Devina dan Devie 2013).

\section{Keunggulan Kompetitif}

Bharadwaj et, al (1993, p83-84) menjelaskan bahwa keunggulan bersaing merupakan hasil dari implementasi strategi yang memanfaatkan berbagai sumber daya yang dimiliki perusahaan. Keahlian dan asset yang unik merupakan kemampuan perusahaan untuk menjadikan para karyawannya sebagai bagian penting dalam pencapaian keunggulan bersaing. Kemampuan perusahaan dalam mengembangkan keahlian para karyawannya dengan baik akan menjadikan perusahaan tersebut unggul dan penerapan strategi yang berbasis sumber daya manusia akan sulit untuk ditiru oleh perusahaan pesaing. Keunggulan bersaing sangatlah penting karena hal ini merupakan kapasitas dari sebuah perusahaan untuk dapat menciptakan posisi yang kuat di pasar (Li, B. Ragu-Nathan, T. S. RaguNathan, and Rao, 2006). Pada dasarnya, keunggulan bersaing adalah posisi kedudukan sebuah perusahaan yang lebih unggul dibandingkan pesaingnya.Porter (1990, p,3) juga berpendapat bahwa keunggulan bersaing adalah jantung kinerja pemasaran untuk menghadapi pesaingnya. Keunggulan bersaing diartikan sebagai strategi benefit dari perusahaan yang melakukan kerjasama untuk menciptakan keunggulan bersaing yang terus menerus sehingga perusahaan dapat mendominasi baik dipasar lama maupun dipasar baru. Keunggulan bersaing pada dasarnya tumbuh dari nilai-nilai atau manfaat yang diciptakan oleh perusahaan yang dinikmati para konsumennya.

\begin{tabular}{llr}
\multicolumn{1}{c}{ Keunggulan } & bersaing yang \\
sesungguhnya & terletak pada \\
pengintegrasian & kegiatankegiatan
\end{tabular}
operasional dengan tujuan untuk mencapai sasaran kualitas atau untuk memenuhi kebutuhan pelanggan (Prahalad and HameldalamDevina dan Devie 2013). Pada saat terciptanya hubungan antara kemampuan dengan atribut yang bernilai bagi pasar, disanalah makna dari keunggulan bersaing itu (Agha, Alrubaiee, and Jamhour, 2012). Tidak hanya menunjukkan kinerja yang lebih baik dibandingkan pesaing, keunggulan bersaing juga harus memberikan nilai yang sebenarnya bagi konsumen. Dari sanalah, maka keunggulan bersaing akan memastikan tercapainya posisi yang dominan di pasar.Beberapa indikator yang dapat digunakan untuk mengukur unggulan bersaing suatu perusahaan. $\mathrm{Li}$ et al dalam prayhoego 
dan devie (2012) mengukur keunggulan bersaing perusahaan dengan menggunakan indikator harga, kualitas, delivery dependability, inovasi produk,

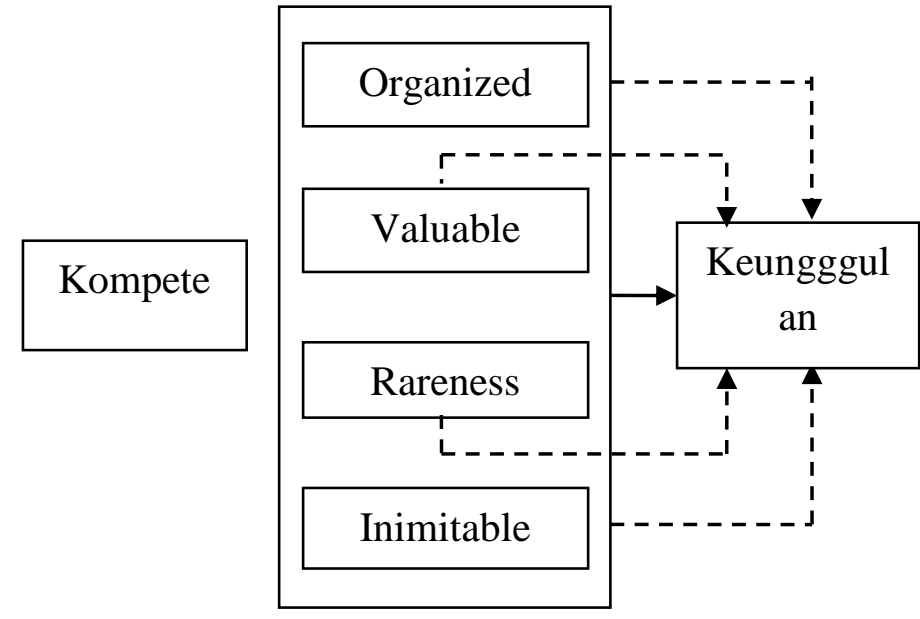

Keterangan:

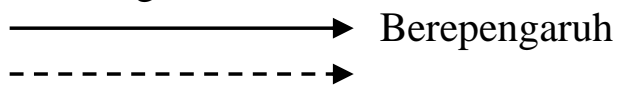

secara simultan

secara parsial

Berpengaruh

\section{METODE PENELITIAN}

Penelitian ini menggunakan pendekatan kuantitatif dalam usaha menguji hipotesis yang disusun.Penelitian ini bertujuan untuk menganalisi kompetensi karyawanorganized, valuable, rareness, dan inimitable secara simultan dan parsial terhadap pencapaian keunggulan kompetitif.Penelitian ini difokuskan pada bidang sumber daya manusia yaitu mengenai kompetensi karyawan yang mempengaruhi terhadap pencapaian keunggulan kompetitif perusahaan pada UD. SR. Hj. Diya Food Sampang Madura.

Variabel dalam penelitian ini meliputi variabel independen yaitu kompetensi ini meliputi organized (X1), valuable (X2), rareness (X3), dan inimitable (X4), serta variabel dependen yaitu keunggulan kompetitif (Y). dan time to market. Kelima indikator ini juga digunakan oleh Thatte (2007) dalam penelitiannya.

Gambar 1. Kerangka Pemikiran. dengan indikator variabel sebagai berikut:

Tabel 1. Variabel Penelitian.

\begin{tabular}{|c|c|c|}
\hline Variabel & Indikator & Item \\
\hline \multirow{7}{*}{$\begin{array}{l}\text { Organize } \\
\text { d } \\
(\mathrm{X} 1)\end{array}$} & \multirow[t]{3}{*}{$\begin{array}{l}\text { Insentif/rew } \\
\text { ard }\end{array}$} & $\begin{array}{l}\text { Kesejahteraan } \\
\text { karyawan }\end{array}$ \\
\hline & & $\begin{array}{l}\text { Jaminan } \\
\text { keberhasilan } \\
\text { karyawan }\end{array}$ \\
\hline & & $\begin{array}{l}\text { Penghargaan } \\
\text { yang } \\
\text { berprestasi }\end{array}$ \\
\hline & \multirow[t]{2}{*}{$\begin{array}{l}\text { Pendidikan } \\
\text { pelatihan }\end{array}$} & $\begin{array}{l}\text { Memberikan } \\
\text { pelatihan }\end{array}$ \\
\hline & & $\begin{array}{l}\text { Wawasan } \\
\text { pengetahuan } \\
\text { untuk } \\
\text { kemajuan } \\
\text { perusahaan } \\
\end{array}$ \\
\hline & System & $\begin{array}{l}\text { Breaving } \\
\text { karyawan }\end{array}$ \\
\hline & Kebijakan & $\begin{array}{l}\text { Organisasi } \\
\text { tidak saja } \\
\text { mengejar } \\
\text { produktivitas } \\
\text { kerja }\end{array}$ \\
\hline \multirow[t]{6}{*}{$\begin{array}{l}\text { Veluabel } \\
\text { (X2) }\end{array}$} & \multirow[t]{3}{*}{ Prilaku inti } & $\begin{array}{l}\text { Keterampilan } \\
\text { muncul dari } \\
\text { diri pribadi }\end{array}$ \\
\hline & & $\begin{array}{l}\text { Mempunyai } \\
\text { nila }\end{array}$ \\
\hline & & $\begin{array}{l}\text { Dukungan dari } \\
\text { pihak lain atas } \\
\text { kreatifnya }\end{array}$ \\
\hline & \multirow{3}{*}{$\begin{array}{l}\text { Prilaku } \\
\text { spesifik } \\
\text { yang } \\
\text { situasional } \\
\text { (situation } \\
\text { specific } \\
\text { behavior) } \\
\end{array}$} & $\begin{array}{l}\text { Keterampilan } \\
\text { yang sesuai }\end{array}$ \\
\hline & & $\begin{array}{l}\text { Memberikan } \\
\text { nilai dan } \\
\text { kepuasan }\end{array}$ \\
\hline & & $\begin{array}{l}\text { Memperhatika } \\
\text { n progres }\end{array}$ \\
\hline \multirow[t]{3}{*}{$\begin{array}{l}\text { Rareness } \\
\text { (X3) }\end{array}$} & \multirow[t]{2}{*}{ Atribut } & $\begin{array}{l}\text { Keahlian } \\
\text { individu }\end{array}$ \\
\hline & & Inovasi sendiri \\
\hline & Kompetensi & $\begin{array}{l}\text { Penentukan } \\
\text { keunggulan }\end{array}$ \\
\hline
\end{tabular}




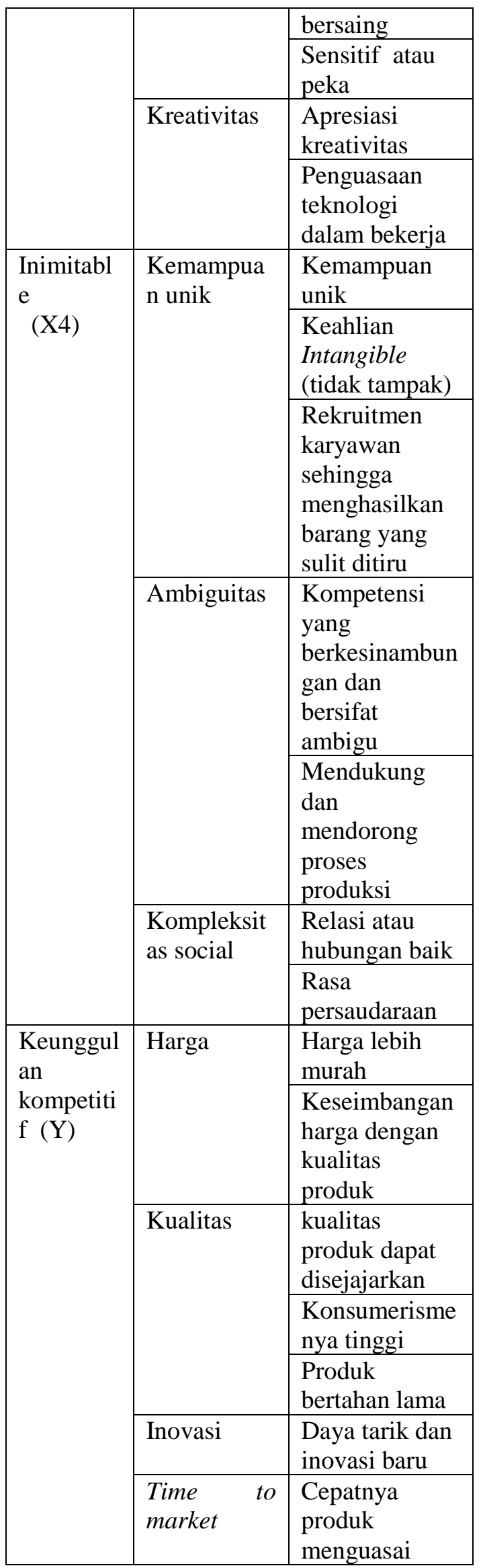

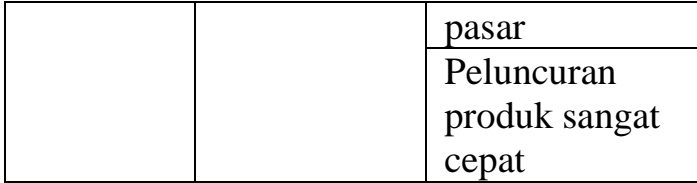

Sumber: Data primer (diolah,2018)

Dalam penelitian ini sampel yang diambil adalah keseluruhan dari populasi, yaitu 53 sampel, karena populasinya kurang dari 100 dengan menggunakan teknik non-random/nonprobability sampling. Pengukuran dalam penelitian ini menggunakan skala Likert dengan lima pembobotan. Teknik pengambilan data menggunakan observasi, interview, dokumentasi, serta kuesioner. dalam penelitian ini juga dilakukan uji validitas dan uji reliabilitas pada instrumen penelitian. Dalam penelitian ini metode analisis data yang digunakan adalah regresi berganda. dimana secara umum data hasil pengamatan $\mathrm{Y}$ dipengaruhi oleh beberapa variabel bebas $\mathrm{X}_{1}, \mathrm{X}_{2}$, $\mathrm{X}_{3}, \ldots, \mathrm{X}_{\mathrm{n}}$, sehingga rumus umum dari regresi linier berganda ini adalah (Dajan,

1984:325): $\mathrm{Y}=\mathrm{a}+\mathrm{b}_{1} \mathrm{X}_{1}+\mathrm{b}_{2} \mathrm{X}_{2}+\mathrm{b}_{3} \mathrm{X}_{3}+\mathrm{b}_{4} \mathrm{X}_{4}+\mathrm{b}$ ${ }_{\mathrm{n}} \mathrm{X}_{\mathrm{n}}+\mathrm{e}$, dimana: $\mathrm{Y}=$ variabel terikat, $\mathrm{a}=$ konstanta, $\mathrm{b}=$ koefisien regresi, $\mathrm{x}=$ variabel bebas. dan $\mathrm{e}=$ error term. sedangkan untuk menguji hipotesis menggunakan uji $\mathrm{T}$ dan Uji F.

\section{HASIL DAN PEMBAHASAN Hasil Penelitian}

Penelitian ini dilaksanakan pada UD. SR. Hj. Diya Food merupakan perusahaan UMKM yang bergerak dibidang produksi bahan baku yang berupa produk petis dari aneka ragam rasa dan terasi yang terbuat dari udang. Perusahaan ini bergerak selama 35 tahun, sejak pencanangan pertama pada tanggal 25 Agustus 1980. Kantor pusat UD. SR. Hj. Diya Food bertempat di Jl. Mutiara No. 105 Banyuanyar Sampang Madura. sampai saat ini UD. SR. Hj. 
Diya Food sudah menghasilkan 35 macam rasa dan 13 jenis produk petis, diantaranya petis dalam bentuk cair seperti kecap dan saus yang merupakan hasil dari pengembangan petis padat produk lama. Petis dalam bentuk kecap dan saus itu memiliki beraneka rasa, seperti rasa pedas, manis, atau asin. Tidak lepas dari 35 macam rasa, UD. SR. Hj. Diya Food ini sudah mempunyai 2 cabang yang terletak di Surabaya dan Jakarta.Berdasarkan hasil penelitian yang telah dilakukan dimana penelitian ini menggunakan sensus dan diambil semua karyawan UD. SR. Hj. Diya Food yang berjumlah 53 orang karyawan, dan diperoleh gambaran umum mengenai hasil penelitian sebagai berikut:

\section{Hasil Uji Validitas}

Validitas menunjukkan sejauh mana alat pengukur tepat untuk mengukur apa yang diukur. Menurut Arikunto (2002:144), validitas adalah suatu ukuran yang menunjukkan tungkat kevalidan atau kesahihan suatu instrument.Berdasarkan hasil uji validasi diatas dapat diketahui bahwa semua item pernyataan memiliki nilai $r$ hitung $>r$ tabel $(0,270)$ atau nilai signifikansi < alpha $(0,05)$ sehingga dapat dikatakan semua item pernyataan telah valid. Berdasarkan hasil penelitian dapat diketahui bahwa semua item pernyataan memiliki nilai $r$ hitung $>r$ tabel $(0,270)$ atau nilai signifikansi < alpha $(0,05)$ sehingga dapat dikatakan semua item pernyataan telah valid.

\section{Hasil Uji reliabilitas}

Reliabilitas menunjukkan konsistensi suatu intrumen dalam mengukur gejala yang sama. Reliabilitas adalah indeks yang menunjukkan sejauh mana suatu alat pengukur dapat dipercaya atau dapat diandalkan.Berdasarkan uji reliabiltas dapat diketahui bahwa semua variabel tersebut memiliki nilai koefisien Alpha Cronbach lebih besar dari 0,6 dengan nilai variabel X1 $(0,735), \mathrm{X} 2(0,872)$, X3 $(0,912)$ X4 $(0,752)$ dan Y $(0,727)$, sehingga dapat dikatakan instrumen pertanyaan yang digunakan dalam penelitian ini sudah reliabel atau dapat dihandalkan.

\section{Hasil uji asumsi Klasik}

Pengujian asumsi model regresi meliputi uji asumsi normalitas, multikolinieritas, dan heteroskedatisitas. Uraian dari penghitungan pengujian asumsi model regresi dapat dijelaskan sebagai berikut:

1. Untuk mendeteksi ada atau tidaknya multikolinieritas dapat dilihat dari Variance Inflation Factor (VIF).Apabila nilai VIF $>10$ maka menunjukkan adanya multikolinieritas, dan apabila sebaliknya VIF < 10 maka tidak terjadi multikolinieritas.

Tabel 2. Hasil Uji Multikolinieritas

\begin{tabular}{|c|c|c|}
\hline $\begin{array}{c}\text { Variabel } \\
\text { Independ } \\
\text { en }\end{array}$ & VIF & Keterangan \\
\hline X1 & $\begin{array}{c}1.45 \\
4\end{array}$ & $\begin{array}{c}\text { Non } \\
\text { Multikolinierit } \\
\text { as }\end{array}$ \\
\hline X2 & $\begin{array}{c}2.14 \\
8\end{array}$ & $\begin{array}{c}\text { Non } \\
\text { Multikolinierit } \\
\text { as }\end{array}$ \\
\hline X3 & $\begin{array}{c}3.83 \\
1\end{array}$ & $\begin{array}{c}\text { Non } \\
\text { Multikolinierit } \\
\text { as }\end{array}$ \\
\hline X4 & 2.57 & $\begin{array}{c}\text { Non } \\
\text { Multikolinierit } \\
\text { as }\end{array}$ \\
\hline
\end{tabular}

Sumber: Data primer (diolah, 2018)

Dari hasil perhitungan yang ada di Tabel 4.11 masing-masing variabel bebas menunjukkan nilai VIF yang tidak lebih dari 10, maka asumsi tidak terjadi multikolinieritas telah terpenuhi. 
2. Pada model regresi yang baik tidak terjadi heteroskedastisitas. Deteksi ada tidaknya pola tertentu pada grafik scatterplot. Apabila ada pola tertentu yang teratur, seperti titik-titik yang ada membentuk pola yang teratur (bergelombang, melebar dan kemudian menyempit), maka mengindikasikan telah terjadi heteroskedastisitas. Sebaliknya, apabila tidak ada pola yang jelas, serta titik-titik menyebar diatas atau dibawah 0 pada sumbu Y, maka tidak terjadi heteroskidastisitas. Hasil pengujian heteroskidastisitas dapat dilihat pada grafik scatterplot berikut:

Gambar 1. Grafik Scatterplot pada Uji Heteroskidastisitas

Scatterplot

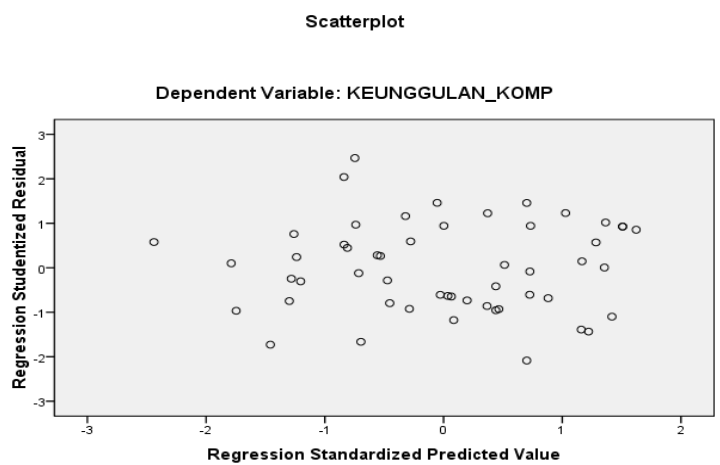

Sumber: Data primer (diolah, 2018)

Berdasarkan grafik scatterplot tersebut terlihat bahwa titik-titik menyebar secara acak baik diatas maupun dibawah angka 0 pada sumbu Y. Dengan demikian dapat disimpulkan bahwa tidak terjadi heteroskidastisitas pada model regresi, sehingga model regresi layak dipakai untuk memprediksi pengaruh variabel organized, valuable, rareness dan inimitable terhadap pencapaian keunggulan kompetitif.

3. Model regresi dapat dikatakan memenuhi asumsi normalitas jika galat atau residual yang disebabkan oleh model regresi berdistribusi normal.Untuk menguji asumsi ini, digunakan grafik PP-Plot. Jika nilai standardized residual atau nilai galat dituangkan dalam sebuah grafik PP-Plot, maka terlihat bahwa plot dari galat tersebut berbentuk suatu pola yang mendekati garis lurus seperti gambar berikut:

Gambar 2. Diagram PP-Plot padaUji Normalitas

Normal P-P Plot of Regression Standardized Residual

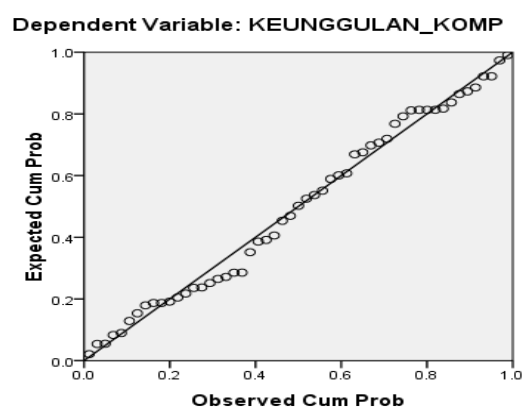

Sumber: Data primer (diolah, 2018)

Pada gambar 2 terlihat titik-titik menyebar disekitar garis diagonal dari arah kiri bawah menuju kanan atas sehingga memenuhi asumsi normalitas.Dan jika nilai galat dikelompokkan dalam sebuah histogram, maka galat-galat tersebut akan membentuk suatu pola kurva distribusi normal, yakni galat tersebut mengelompok pada bagian tengah dengan titik puncaknya 
berada pada rata-rata sama dengan 0,000 seperti pada Gambar berikut:

Gambar 3. Histogram pada Uji Normalitas

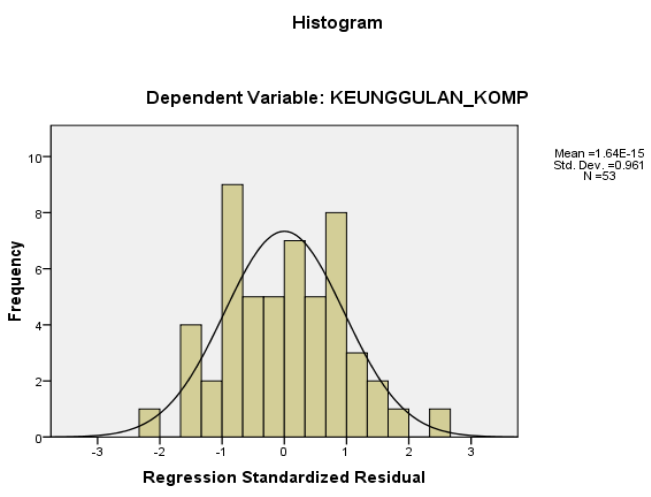

Sumber: Data primer (diolah, 2018)

\section{Analisis regresi linier berganda}

Teknik analisis data yang digunakan dalam penelitian ini adalah analisis regresi linier berganda.Analisis regresi linier berganda adalah suatu metode statistik umum yang digunakan untuk meneliti hubungan antara sebuah variabel dependen dengan beberapa variabel independen. Berdasarkan hasil pengelohan data dengan menggunakan Software hasil analisis sebagai berikut:

Tabel 3. Hasil Analisis Regresi.

$\begin{array}{cccc}\text { Variabel } & \begin{array}{c}\text { Standardized } \\ \text { Coefficients } \\ \text { Beta }\end{array} & \text { thitung } & \text { Sig. } \\ \text { X1 } & 0,159 & 1,108 & 0,273 \\ \text { X2 } & 0,004 & 0,023 & 0,982 \\ \text { X3 } & 0,029 & 0,125 & 0,901 \\ \text { X4 } & 0,468 & 2.447 & 0,018 \\ \text { Keterangan: } & & & \end{array}$

$$
\begin{array}{lr}
\mathrm{R} & =0.563^{\mathrm{a}} \\
\mathrm{R} \text { Sguare } & =0.317 \\
\text { Adjusted R Square } & =0.260 \\
\mathrm{~T}_{\text {tabel }} & =2,010 \\
\mathrm{~F}_{\text {hitung }} & =5,566
\end{array}
$$

$\mathrm{F}_{\text {tabel }}=2,528$

Sumber: Data primer (diolah, 2018)

Berdasarkan hasil analisis regresi linier berganda tersebut, maka dapat dibuat suatu persamaan regresi sebagai berikut: untuk variabel Organized (X1) menghasilkan koefisien variabel organized sebesar 0,159 . Tanda positif menunjukkan variabel organized dengan variabel keunggulan kompetitif mempunyai sifat hubungan searah. Dari hasil uji pearson correlation hubungan antara variabel organized dengan keunggulan kompetitif mempunyai nilai sebesar 0,324, dan hubungan tersebut rendah, karena nilai koefisien berada diantara nilai $0,20-0,399$. Sehingga dengan penambahan faktor organized akan meningkatkan keunggulan bersaing. Sedangkan variabel Valuble (X2) menujukkan koefisien variabel valuable sebesar 0,004. Tanda positif menunjukkan variabel valuable dengan variabel keunggulan kompetitif mempunyai sifat hubungan searah. Dari hasil uji pearson correlation hubungan antara variabel valuable dengan keunggulan kompetitif mempunyai nilai sebesar 0,369, dan hubungan tersebut rendah, karena nilai koefisien berada diantara nilai $0,20-0,399$. Sehingga dengan penambahan faktor valuable akan meningkatkan keunggulan bersaing pada.

Untuk variabel Rareness (X3) Menujukan koefisien variabel rareness sebesar 0,029. Tanda positif menunjukkan variabel rareness dengan variabel keunggulan kompetitif mempunyai sifat hubungan searah, Dari hasil uji pearson correlation hubungan antara variabel rareness dengan keunggulan kompetitif mempunyai nilai sebesar 0,472, dan hubungan tersebut sedang, karena nilai koefisien berada diantara nilai $0,40-0,599$. Sehingga 
dengan penambahan faktor rareness akan meningkatkan keunggulan bersaing pada. sedangkan variabel Inimitable (X4) menujukan koefisien variabel inimitable sebesar 0,468 . Tanda positif menunjukkan variabel inimitable dengan variabel keunggulan kompetitif mempunyai sifat hubungan searah. Dari hasil uji pearson correlation hubungan antara variabel inimitable dengan keunggulan kompetitif mempunyai nilai sebesar 0,540 , dan hubungan tersebut sedang, karena nilai koefisien berada diantara nilai $0,40-$ 0,599 . Sehingga dengan penambahan faktor inmitability akan meningkatkan keunggulan bersaing pada.

Selain itu, karena variabel independen lebih dari satu, maka dilihat dari nilai Koefisien determinasi $R$ Square. Koefisien determinasi R Square (R2) pada intinya mengukur seberapa jauh kemampuan model dalam menerangkan variasi variabel dependen. Nilai koefisien determinasi adalah antara nol dan satu.Nilai R2 yang kecil berarti kemampuan variabel-variabel independen dalam menjelaskan variasi variabel dependen sangat terbatas.

Tabel 4. Hasil Koefisien Determinasi $\left(\mathrm{R}^{2}\right)$

\begin{tabular}{|c|c|c|c|c|}
\hline $\begin{array}{c}\text { Mo } \\
\text { del }\end{array}$ & $\mathrm{R}$ & $\begin{array}{c}\mathrm{R} \\
\text { Square }\end{array}$ & $\begin{array}{c}\text { Adjusted } \mathrm{R} \\
\text { Square }\end{array}$ & $\begin{array}{c}\text { Std. Error of the } \\
\text { Estimate }\end{array}$ \\
\hline 1 & $.563^{\mathrm{a}}$ & .317 & .260 & 2.032 \\
\hline
\end{tabular}

a. Predictors: (Constant), INIMITABLE,

ORGANIZED, VALUABLE, RARENESS

Sumber: Data primer (diolah, 2018)

R Square sebesar 0,317 berarti bahwa $31,7 \%$ variabel dependen keunggulan kompetitif (Y) dipengaruhi oleh variabel bebas organize (X1), valuable (X2), rareness (X3), dan inimitable (X4), sedangkan $68,3 \%$ dipengaruhi oleh sebab lain.Koefisien korelasi berganda $\mathrm{R}$ (multiple correlation) menggambarkan kuatnya hubungan antara variabel bebas yang meliputi variabel Organize, Valuable, Rareness dan Inimitable secara bersama-sama memberikan pengaruh terhadap variabel terikat, yaitu variabel keunggulan kompetitif (Y), dengan nilai $\mathrm{R}$ (multiple correlation) adalah sebesar 0,563 . Hal ini berarti keseluruhan variabel bebas mempunyai hubungan erat, karena nilai $\mathrm{R}$ tersebut mendekati 1.

\section{Pembahasan}

Keunggulan bersaing sebuah perusahaan harus didasarkan pada sumberdaya khusus yang menjadi penghalang aktivitas peniruan produk atau jasa perusahaan. Meningkatnya tekanan persaingan dapat menurunkan keunggulan bersaing perusahaan. Hal ini mengindikasikan bahwa bagi sebuah perusahaan, agar tetap bertahan hidup (survive) di tengah tekanan persaingan yang semakin tajam, perusahaan harus mengambil tindakan yang dapat mempertahankan dan memperkuat kompetensinya yang unik, mempunyai nilai, jarang ditiru, dan paham betul terhadap organisasi.Dalam Absah (2008), Prahalad and Hamel (1989) menemukan bahwa perusahaan yang sukses adalah perusahaan yang berfokus pada peningkatan kompetensi, yang digunakan dengan cara-cara baru dan inovatif untuk mencapai tujuan. Perhatian utama perusahaan adalah menggunakan sumberdayanya dalam cara-cara yang menantang dan kreatif untuk membangun kompetensi inti.

Pengetahuan yang dimiliki karyawan perusahaan menjadi salah satu kompetensi yang sulit ditiru. Pengetahuan akan menjadi kompetensi yang sulit untuk ditiru karena membutuhkan waktu yang lama dan 
biaya yang mahal untuk ditiru. Selain itu seseorang dengan keahlian khusus yang dimiliki perusahaan akan menjadi menjadi keunggulan strategis dan merupakan basis bagi kinerja superior. Seperti juga yang ditemukan oleh Hatch and Dyer (2004) bahwa pesaing tidak dapat dengan cepat dan murah meniru atau mengganti nilai dari sumberdaya manusia khusus yang dimiliki perusahaan. Dan begitu banyak penelitianyang lain yang mengemukakan bahwa dengan faktor kompetensi akan menjadikan sebuah perusahaan menjadi unggul dalam sebuah persaingan, karena dalam kompetensi itu juga akan muncul karakter yang ambiguitas. Secara teori persaingan, ambiguitas merupakan hal yang sulit ditiru oleh perusahaan lain, karena kompetensinya tidak pernah jelas dan kasat mata. Dalam penelitian ini organized, valuable, rareness dan inimitable merupakan sebuah faktor keberhasilan sebuah organisasi atau perusahaan untuk menciptakan keunggulan kompetitif. Penerapan empat kompetensi tersebut akan menghindari kelesuan perusahaan dari persaingan yang semakin terjadi di era modernisasi ini. Oleh karena itu, organized, valuable, rareness daninimitable merupakan senjata untuk menyerang dan melawan persaingan dari berbagai kompetitor organisasi. Oleh karenanya Rifai, Warter, dan Poppy (2015) menyatakan pemberdayaan organisasi usaha kecil dan menengah semacaram ini perlu terus ditingkatkan agar bisa mensejahterakan masyarakat secara luas.

\section{PENUTUP}

Berdasarkan hasil penelitian yang telah dilakukan dapat disimpulkan bahwaecara simultan, dengan dilakukan uji F, diketahui bahwa organized, valuable, rareness dan inimitable berpengaruh terhadap pencapaian keunggulan kompetitif. Dengan demikian, apabila faktor organized, valuable, rareness dan inimitable bersama-sama ditingkatkan, maka keunggulan kompetitif UD. SR. Hj. Diya Food akan semakin meningkat.Secara parsial, dengan dilakukannya uji $\mathrm{T}$, diketahui bahwa organized, valuable, rareness dan inimitable berpengaruh terhadap pencapaian keunggulan kompetitif, dimana dari masing-masing dari variabel tersebut mempunyai $\mathrm{T}$-hitung yang lebih besar dari T-tabel. Dengan demikian, apabila faktor organized, valuable, rareness dan inimitable masing-masing meningkat, maka keunggulan kompetitif UD. SR. Hj. Diya Food akan semakin meningkat.

\section{DAFTAR PUSTAKA}

Absah, Yeni, 2008, Kompetensi: Sumber daya Pendorong Keunggulan Bersaing Perusahaan, Jurnal Manajemen Bisnis, Vol. 1 No. 3, Hal. 109116: Universitas Sumatera Utara.

Arikunto, Suharsimi. 2006. Prosedur Penelitian- Suatu Pendekatan Praktik. Jakarta: PT RINEKA CIPTA.

Becker, K. F. (2004), The Informal Sector: Fact Finding Study (www.worldbank.org)

Hatch, N.W. and J.H. Dyer, 2004. Human Capital and Learning as a Source of Sustainable Competitive Advantage, Strategic Management Journal, Vol.25, pp. 1155-1178.

Jufrisen dan Parlindungan, Roni, 2014, Soft Competency: Upaya Meningkatkan Keunggulan Kompetitif Perusahan Dalam 
Era Persaingan Global (pendekatan RBV), jurnal riset akuntansi dan bisni, vol 14 no. 1. Universitas muhammadiyah sumatera utara.

Mangkruprawira, sjafri, 2002, Manajemen Sumber Daya Manusia Strategik, bogor: Ghalia Indonesia

Muhamad Rifai, Warter Agustim, Poppy Indrihastuti, 2015, Analisis Pemberdayaan Masyarakat Home Industry dalam Rangka Mendorong Kemandirian Ekonomi, Jurnal Bisnis Perspektif, FE Unika Darma Cendikia Surabaya, Volueme 7 no. 2 hal. 171-180. http://www.ukdc.ac.id/jurnal/ind ex.php/BIPS/article/view/83/177

Pono, Maat, 2010. Strategi Pengembangan Kompetensi Inti Industri Daerah Kabupaten Tojo Una-Una Sulawesi Tengah, Universitas Hasanuddin, Sulawesi Tengah.

Porter, M. E. 1985 The Competitive Advantage: Creating and Sustaining Superior Performance. NY: Free Press.

Prahalad, C.K. and G. Hamel, 1989. Strategic Intent, Harvard Business Review, May-June, pp. 63- 76.

Roen, Ferry, 2013. Teori Pendekatan Keahlian, (online), (perilakuorganisasi.com/teoripendekatan-keahlian.html).

Suliyanto, 2006, Metode Riset Bisnis, Penerbit Andi, Yogyakarta.

Spencer, L.M dan spencer, S.M, 1993. Competence at Work, John Wiley \& Sons, (Online), (http://jurnalsdm.blogspot.com/2009/09/kons ep-kompetensidefinisi.html?m=1).
Teguh, Devina, Evelyn dan Devie, 2013, Analisa Pengaruh Core Competencies Terhadap Keunggulan Bersaing dan Kinerja Perusahaan, Business Accounting Review, VOL 1, Universitas Kristen Petra.

Uma Sekaran, 2007, Metodelogi Penelitian Untuk Bisnis, Selemba Empat, Jakarta.

Rivai, Veithzal dan Ella Jauvani Sagala, 2009, Manajemen Sumber Daya Manusia untuk Perusahaan, Rajawali Pers, Jakarta. 